\title{
Przedswięwzięcia zwiększające prognozowaną żywotność osi zestawów kołowych w skali Unii europejskiej
}

\author{
$W$ artykule przedstawiono metody zwiększenia bezpieczeństwa i niezawodności osi \\ zestawów kołowych na przykładzie wagonów towarowych. Poruszono istotne pro- \\ blemy zwiqzane z projektowaniem osi zestawów kolowych zespotów trakcyjnych \\ dalekobieżnych, gdzie zaproponowano bardziej ostrożne podejście do przyjmowa- \\ nia naprężen dopuszczalnych, wynikajacych z bardzo dużego przebiegu kilome- \\ trowego. Artykut zostat opracowany w ramach projektu badawczo-rozwojowego \\ Nr R 10 004806/2009 pt. „,Mikroprocesorowy system diagnostyczny głównych \\ systemów trakcyjnego pojazdu szynowego uwzględniajacy ocenę bieżaca i progno- \\ zowanie stanów", finansowanego z budżetu Ministerstwa Nauki i Szkolnictwa Wyż- \\ szego. \\ Projekt badawczy własny $n r N$ N509 pt. "Prognozowanie stanu technicznego \\ głównych systemów pojazdu szynowego na podstawie analizy zmian wartości cha- \\ rakterystycznych parametrów podzespołów".
}

\section{WSTĘP}

Problematyka związana z rozwojem technologii wytwarzania osi zestawów kołowych została przedstawiona w opracowaniach $[4,8,12]$. Bardzo duża rolę odgrywa wprowadzenie normy europejskiej PN-EN 13261+A1:2011 [19], która zastąpiła dotychczas obowiązująca kartę UIC 811-1 [15] oraz PN-93/K-91045 [20]. Zwiększa się również rola diagnostyki w niezawodnej eksploatacji zestawów kołowych $[6,7,9,10,11,13,14,16,19,22]$. Niezależnie od wzrastającego nacisku położonego na jakość technologii wytwarzania po katastrofie kolejowej pociagu towarowego, ciagnacego wagony towarowe-cysterny w Viareggio (Włochy) podjęto $\mathrm{w}$ Europie szeroko zakrojoną akcję prewencyjna, mającą na celu zapobieżenie podobnym wypadkom oraz mających na celu zwiększenie bezpieczeństwo eksploatacji osi zestawów kołowych. Ww. akcję uzasadniano również faktem zwiększającej się liczby wypadków wagonów towarowych w skali europejskiej, wynikających ze źle utrzymanych zestawów kołowych. Współpraca w tym temacie została podjęta roku przez Europejską Agencję Kolejową (niem. „Europäische Eisenbahnagentur”- ERA), krajowe urzędy transportu kolejowego, odpowiedzialne za bezpieczeństwo ruchu kolejowego oraz przedsiębiorstwa kolejowe (koleje państwowe oraz prywatne, właściciele wagonów oraz producenci, zrzeszone w UIP). Ww. grupa Joint Sektor Group opracowała program roboczy, mający na celu zwiększenie bezpieczeństwa eksploatacji wagonów towarowych i został on zatwierdzony przez Unię Europejską i krajowe urzędy transportu kolejowego. Celem programu rozwiniętego przez JSG jest eliminacja zagrożeń eksploatacyjnych na podstawie przeprowadzonej kontroli wizualnej i dalsza optymalizacja opanowania możliwego ryzyka $\mathrm{w}$ eksploatacji zestawów kołowych w eksploatacji zestawów kołowych europejskich wagonów towarowych, których łączny przebieg kilometrowy wynosi ok. 50 miliardów kilometrów w ciągu roku.

Grupa JSG skupiała członków następujących organizacji kolejowych:

$\Rightarrow$ Związku Kolei Europejskich - CER

$\Rightarrow$ Związku Prywatnych Przedsiębiorstw Przewozowych Ładunków - EFRA

$\Rightarrow$ Związku Prywatnych Właścicieli Wagonów Towarowych - UIP

$\Rightarrow$ Związku Operatorów Transportu Kombinowanego - UIRR

$\Rightarrow$ Związku Producentów Zestawów Kołowych UNIFE.

\section{OPIS PROGRAMU OPRACOWANEGO PRZEZ JSG}

Program roboczy składa się z trzech zakresów dzialań.

Zakres I. Opracowanie Katalogu Wizualnej Kontroli Uszkodzeń Osi Zestawów Kołowych tzw. EVICKatalog (ang. European Visual Inspection Catologue), opisuje lub przedstawia przykładowe referencyjne uszkodzenia mechaniczne lub uszkodzenia spowodowane procesami korozji osi zestawów kołowych. Kontrola wizualna osi jest przewidziana naprawach lub przeglądach wagonów towarowych w warsztacie, jeśli wagon znajduje się na kanale lub jest podniesiony. Zestawy kołowe, które wykazują wady niedopuszczalne, należy wyłączyć z eksploatacji i przeprowa- 
dzić naprawę przy użyciu badań nieniszczących. Skatalogowane kryteria uszkodzeń EVIC są obligatoryjne od 1.04.2010. Okres trwania programu jest ograniczony tzn.:

- standardowe wagony towarowe muszą być sprawdzone co 6 lat

- wagony przewożące ładunki niebezpieczne, które są eksploatowane w agresywnym środowisku muszą być sprawdzone w co 4 lata.

Katalog uszkodzeń EVIC musi być przekazany warsztatom naprawczym przez właścicieli, zlecającym przeglądy osi zestawów kołowych i są one zobowiązane do przekazywania informacji o wykonanych przeglądach. Joint Sektor Group opracował specjalny dokument $\mathrm{z}$ danymi, które podlegają kontroli. W celu wdrożenia i kontroli programu wyznaczono w poszczególnych krajach krajowe gremia Joint EVIC Bodies, do których zadań należało przetłumaczenie katalogu EVIC na język danego kraju oraz organizacja szkoleń dla zainteresowanych organizacji kolejowych, właścicieli i warsztatów naprawczych. Katalog EVIC został przetłumaczony na 11 języków krajów, zrzeszonych w Unii Europejskiej. Przeprowadzono około 50 kursów szkoleniowych z udziałem $\mathbf{7 5 0}$ uczestników. Od czasu startu programu zostało przebadanych 180000 osi wagonów towarowych w krajach członkowskich Unii Europejskiej. Struktura kontroli w poszczególnych krajach Unii Europejskiej jest przedstwiona w tabeli 1 .
$\mathrm{Z}$ danych przedstawionych $\mathrm{w}$ tabeli 1 widoczna jest wiodąca rola kolei niemieckich we wdrażaniu nowego systemu kontrolnego. Łącznie zostało przebadanych 93607 osi zestawów kołowych wagonów towarowych, co stanowi 70\% łącznej ilości przebadanej w ramach kolei krajów członkowskich Unii Europejskiej. Zaskakujący jest przy tym fakt pozytywnie zweryfikowanych osi zestawów kołowych, wynoszących 44126, co stanowi zaledwie 33\% łącznej ilości przebadanej w ramach kolei krajów członkowskich Unii Europejskiej. Znacznie lepszy wyniki takiej kontroli moga odnotować przewoźnicy, których koleją podstawiającą są koleje francuskie, przy zastrzeżeniu że kontroli poddano znacznie mniejszą ilość osi zestawów kołowych.

Struktura wyników kontrolowanych osi zestawów kołowych wagonów towarowych 86 właścicieli w 12 krajach Unii Europejskiej jest przedstawiona na rys.1.

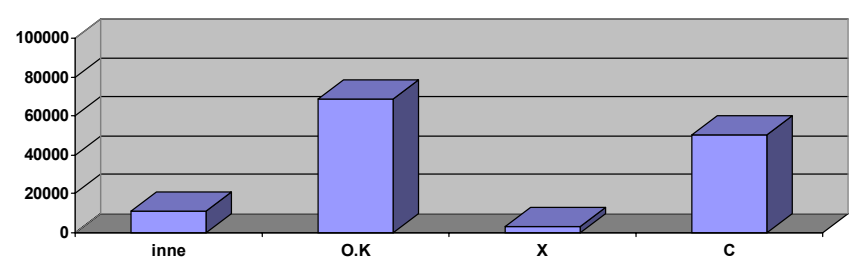

inne) osie wykluczone z eksploatacji z innych powodów

OK) wynik badań nieniszczących pozytywny

$\mathrm{X})$ natychmiastowe wykluczenie osi z eksploatacji

C) wynik badań pozytywny, osie dopuszczone do dalszej eksploatacji.

Rys.1. Wyniki kontrolowanych osi zestawów kołowych wagonów towarowych w krajach Unii Europejskiej

Struktura kontroli osi zestawów kołowych 86 właścicieli wagonów towarowych w 12-tu krajach Unii Europejskiej w ujęciu ilościowym wg [1]

Tabela 1

\begin{tabular}{|c|c|c|c|c|c|c|c|}
\hline L.p. & Kraj & $\begin{array}{c}\text { Ilość } \\
\text { spraw- } \\
\text { dzanych } \\
\text { wagonów }\end{array}$ & $\begin{array}{l}\text { Osie ze- } \\
\text { stawów } \\
\text { kolowych }\end{array}$ & Inne $^{1)}$ & $\begin{array}{c}\text { Wynik } \\
\text { pozytywny } \\
\text { „OK." }\end{array}$ & $\begin{array}{c}\text { Wynik } \\
\text { negatywny } \\
\left., X^{,}, 3\right)\end{array}$ & $\begin{array}{c}\text { Dalsza eks- } \\
\text { ploatacja do } \\
\text { następnej } \\
\text { kontroli } \\
\text {,C,4) } \\
\end{array}$ \\
\hline 1. & $\begin{array}{l}\text { Unia Eu- } \\
\text { ropejska }\end{array}$ & 34356 & 133184 & 11033 & 68983 & 3082 & 50176 \\
\hline 2. & Austria & 980 & 3713 & 1582 & 1301 & 264 & 566 \\
\hline 3. & Belgia & 459 & 1873 & & 1871 & 2 & 0 \\
\hline 4. & Szwajcaria & 1976 & 6639 & 293 & 2706 & 192 & 3348 \\
\hline 5. & Czechy & 19 & 76 & & 76 & 0 & 0 \\
\hline 6. & Niemcy & 23632 & 93607 & 7200 & 44126 & 2140 & 40141 \\
\hline 7. & Estonia & 66 & 161 & 0 & 90 & 12 & 59 \\
\hline 8. & Francja & 3372 & 12396 & 1820 & 9522 & 110 & 944 \\
\hline 9. & Węgry & 271 & 989 & 2 & 580 & 2 & 405 \\
\hline 10. & Włochy & 1768 & 6780 & 82 & 3971 & 309 & 2418 \\
\hline 11. & Polska & 829 & 3253 & 35 & 2723 & 44 & 451 \\
\hline 12. & Słowacja & 966 & 3645 & 10 & 1893 & 5 & 1737 \\
\hline 13. & Słowenia & 18 & 52 & 9 & 34 & 2 & 7 \\
\hline
\end{tabular}

${ }^{1)}$ wykluczone z eksploatacji z innych powodów

2) wynik badań nieniszczących pozytywny, dalsza eksploatacja
3) natychmiastowe wykluczenie z eksploatacji

4) dalsza eksploatacja aż do następnej kontroli wg katalogu EVIC 
Struktura wyników kontrolowanych osi zestawów kołowych wagonów towarowych w Polsce jest przedstawiona na rys.2.

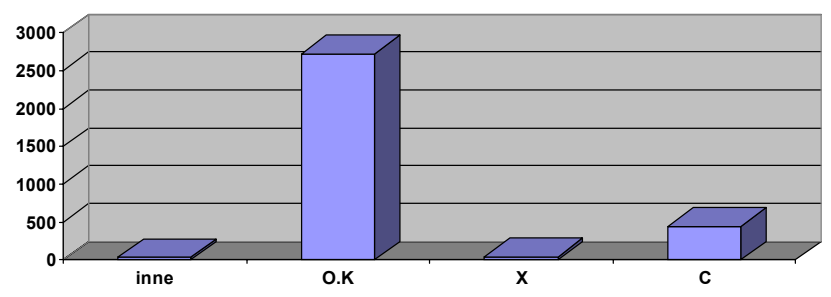

inne) osie wykluczone $\mathrm{z}$ eksploatacji z innych powodów

OK) wynik badań nieniszczących pozytywny

$\mathrm{X)}$ natychmiastowe wykluczenie osi z eksploatacji

C) wynik badań pozytywny, osie dopuszczone do dalszej eksploatacji.

Rys.2. Wyniki kontrolowanych osi zestawów kołowych wagonów towarowych w Polsce w ramach Unii Europejskiej

Na uwage zasługują dobre wyniki, kontroli przeprowadzonej w Polsce. Porównując bardzo podobne ilości przebadanych zestawów kołowych w Austrii, Słowacji oraz $\mathrm{w}$ kraju wg tych samych kryteriów najwięcej zestawów kołowych zostało zakwalifikowanych do dalszej eksploatacji po stwierdzeniu pozytywnego wyniku badań ultradźwiękowych.

Zakres II: Zakres ten programu opracowanego przez JSG jest dostarczenie dowodu, że wizualna inspekcja osi zestawów kołowych eliminuje w sposób niezawodny możliwe ryzyko eksploatacyjne. $Z$ wszystkich czterech zakresów kwalifikacyjnych (oznaczonych „X”, „OK.”, „inne” oraz „C“) wytypowano 24000 osi zestawów kołowych wagonów towarowych, które przeszły $\mathrm{z}$ wynikiem pozytywnym lub nie zostały zakwalifikowane na zgodność z kryteriami EVIC do bardzo szczegółowych badań nieniszczących np. badań ultradźwiękowych. $\mathrm{Na}$ bazie porównań i ocen grupa JSG zobowiązała się do wdrażania dalszych przedsięwzięć technicznych. Realizacja programu jest przewidziana na $\mathbf{1 2}$ miesięcy $i$ będzie koordynowana $\mathrm{w}$ ramach danego państwa i wdrażana, przy czym odpowiednie należy zebrać odpowiednie pliki danych i przekazać dalej po 6-ciu miesiącach. Program jest uzgadniany zarówno przez Unię Europejską jak również krajowe urzędy i rozpoczął się w czerwcu 2010 roku.

Zakres III: Opiera się na propozycji opracowania danych do przeprowadzenia przeglądów zestawów kołowych. Propozycja ta została zgłoszona na posiedzeniu Europejskiej Agencji Kolejnictwa (ERA) w dniu 22.06.2010. Za pomoca odpowiedniej metodyki można dokonać szybkiej identyfikacji wad materiałowych i ułatwić ustalenia przyczyn wypadków kolejowych. Łącznie należy zarejestrować $\mathbf{4 7}$ parametrów dla różnych części składowych zestawów kołowych. Dalej należy zdefiniować badania nieniszczące, które należy wykonać na zestawie kołowym w zależności od sytuacji. System został wprowadzony od sierpnia 2010 roku. Licząc od tej daty muszą być wszystkie dane rejestrowane i wtedy niniejsze dane muszą być rejestrowane na bieżąco we wszystkich w krajach Unii Europejskiej. Od 01.01.2012 dane muszą być rejestrowane w elektronicznym systemie przetwarzania danych.

\section{NOWOCZESNE ZASADY PROJEKTOWANIA ZESTAWÓW KOLOWYCH}

Struktura kontroli osi zestawów kołowych 86 wlaścicieli w 12-tu krajach Unii Europejskiej w ujęciu procentowym wg [1]

Tabela 2

\begin{tabular}{|c|c|c|c|c|c|c|c|}
\hline L.p. & Kraj & $\begin{array}{c}\text { Ilość spraw- } \\
\text { dzanych wa- } \\
\text { gonów }\end{array}$ & $\begin{array}{l}\text { Osie ze- } \\
\text { stawów } \\
\text { kołowych }\end{array}$ & Inne $^{1)}$ & $\begin{array}{c}\text { Wynik } \\
\text { pozytywny } \\
\text { „OK.,"2) }\end{array}$ & $\begin{array}{c}\text { Wynik } \\
\text { negatywny } \\
\left., X^{,}, 3\right)\end{array}$ & $\begin{array}{c}\text { Dalsza eks- } \\
\text { ploatacja do } \\
\text { następnej } \\
\text { kontroli } \\
\text { „C, }\end{array}$ \\
\hline & & & & \multicolumn{4}{|c|}{$[\%]$} \\
\hline 1. & $\begin{array}{l}\text { Unia Euro- } \\
\text { pejska }\end{array}$ & 34356 & 133184 & 8,28 & 51,72 & 2,31 & 37,67 \\
\hline 2. & Austria & 980 & 3713 & 42,6 & 35,03 & 7,11 & 15,24 \\
\hline 3. & Belgia & 459 & 1873 & 0 & 99,89 & 0,106 & 0 \\
\hline 4. & Szwajcaria & 1976 & 6639 & 4,41 & 40,75 & 2,89 & 50,42 \\
\hline 5. & Czechy & 19 & 76 & 0 & 100 & 0 & 0 \\
\hline 6. & Niemcy & 23632 & 93607 & 8,61 & 47,13 & 2,28 & 42,88 \\
\hline 7. & Estonia & 66 & 161 & 0 & 55,90 & 7,45 & 36,64 \\
\hline 8. & Francja & 3372 & 12396 & 14,68 & 76,81 & 0,88 & 7,61 \\
\hline 9. & Węgry & 271 & 989 & 2,02 & 58,64 & 0,20 & 40,95 \\
\hline 10. & Włochy & 1768 & 6780 & 1,20 & 58,56 & 4,55 & 35,66 \\
\hline 11. & Polska & 829 & 3253 & 0,99 & 77,24 & 1,24 & 12,80 \\
\hline 12. & Słowacja & 966 & 3645 & 0,27 & 51,93 & 0,13 & 47,65 \\
\hline 13. & Słowenia & 18 & 52 & 17,3 & 65,38 & 3,84 & 13,46 \\
\hline
\end{tabular}

1) osie wykluczone z eksploatacji z innych powodów

${ }^{2)}$ wynik badań nieniszczących pozytywny
3) natychmiastowe wykluczenie osi z eksploatacji

4) wynik badań pozytywny, osie dopuszczone do dalszej eksploatacji. 
Doświadczenia eksploatacyjne zespołów trakcyjnych, przystosowanych do wysokich prędkości, zwłaszcza ICE w DB AG dostarczyły nowego materiału bazowego do analiz osi pod względem wytrzymałościowym. Przebieg kilometrowy zespołów trakcyjnych dalekobieżnych wynosi około $500000 \mathrm{~km} \mathrm{w}$ skali rocznej (ok. $1370 \mathrm{~km}$ w przeliczeniu na dzień, ok. $57 \mathrm{~km} \mathrm{w}$ przeliczeniu na jedną godzinę).. Dla porównania przebieg zespołów trakcyjnych ruchu lokalnego wynosi około $100000 \mathrm{~km} \mathrm{w}$ skali rocznej. Jak okazuje się z praktyki eksploatacyjnej przy takim intensywnym przebiegu już podczas 21 dni jest osiagnięta bazowa wartość cykli $10^{7}$ cykli. Zakładając średnią średnicę toczną koła $0,900 \mathrm{~m}$, wynika że oś jest obciążona 350 cyklami w przebiegu przeliczeniowym na jeden kilometr, co daje 484000 cykli obciążeń na jeden dzień. $Z$ takich przeliczeń wynika, że zakładając 30-letnią żywotność otrzymuje się łączny przebieg, wynoszący 15 milionów kilometrów, co odpowiada $10^{9}$ cykli obciążeń $\left(\mathbf{1 0 0} \times 10^{7}\right.$ cykli obciążeń). Z tego wynika, że zakładana wartość $10^{7}$ cykli obciążeń jest $\mathrm{w}$ praktyce wielokrotnie przekraczana (nawet 100 razy). W związku z tym wytrzymałość eksploatacyjna takich elementów jak osie nabiera szczególnego znaczenia i zależy od wielu czynników, które są wymienione na rys.3.

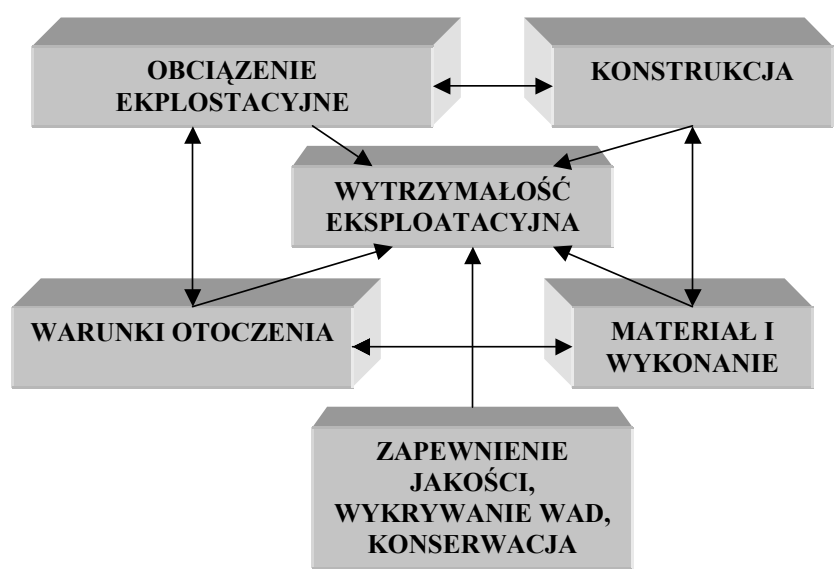

Rys.3. Schemat blokowy czynników mających wpływ na wytrzymałość eksploatacyjną osi zestawów kołowych wraz z ich wzajemnymi powiązaniami

Z przeprowadzonych badań naukowych i doświadczeń praktycznych znane są ograniczenia prostego opisu wytrzymałości zmęczeniowej. Jako istotne ograniczenia należy wymienić:

$\Rightarrow$ najczęściej występujące obciążenia eksploatacyjne nie posiadają charakteru sinusoidalnego, lecz są to obciążenia o zmiennym przebiegu, a wskutek tego występuje mechanizm kumulacji uszkodzeń o odmiennym charakterze

$\Rightarrow$ na częściach występujących w eksploatacji nie można mówić o wytrzymałości zmęczeniowej w tradycyjnym ujęciu, wskutek czego po $10^{6}$ lub $10^{7}$ cykli obciążeń odnotowuje się dalszy spa- dek wytrzymałości co wyznacza krzywa o pochyleniu $\mathrm{k}_{2}$, szczególnie to odczuwa się przy połączeniach wtłaczanych (na odsadzeniach kół, łożysk, kół przekładni i tarcz hamulcowych) i przy występowaniu korozji

$\Rightarrow$ warunek wytrzymałości zmęczeniowej dla osi jest spełniony, jeśli współczynnik bezpieczeństwa S, definiowany jako stosunek pomiędzy naprężeniem dopuszczalnym oraz naprężeniem rzeczywistym. wynikającym z eksploatacji jest większy od 1.; w rzeczywistych warunkach eksploatacyjnych stosunek ten może być mniejszy w wyniku działania ekstremalnego naprężenia, spowodowanego wystapienia maksymalnej siły podczas przejazdu przez tuk toru.

Żywotność przy zmiennej amplitudzie naprężeń i wynikającym z tego układu naprężeń jest opisana przez krzywą Gassnera, która została zastosowana w budowie części pojazdów szynowych w latach 80-tych. Krzywa Gassnera jest przedstawiona na rys.4.

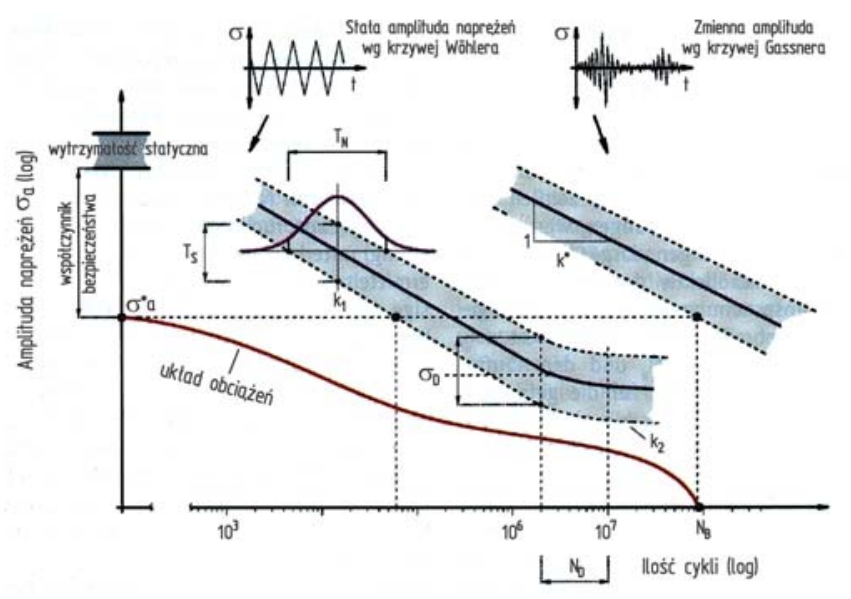

Rys. 4. Określenie amplitudy naprężenia $\sigma_{a}$ wg hipotezy ekwiwalentnych uszkodzeń wg [3]

Została ona opracowana już $w$ latach trzydziestych $\mathrm{XX}$ wieku i wykorzystana w projektowaniu lekkich konstrukcji w przemyśle lotniczym, a następnie wykorzystana również w budowie pojazdów. Również krzywa Gassnera została opisana przez rozproszenie i pochylenie $k^{*}$. Krzywa Gassnera może być zastosowana do charakterystyki wytrzymałości zmęczeniowej przy określonych warunkach brzegowych oraz do oceny wytrzymałości eksploatacyjnej i żywotności przy znanym obciążeniu eksploatacyjnym. Przy przedłożeniu reprezentatywnego układu obciążeń jako układu do konstrukcji dla przewidywanej żywotności wywodzi się naprężenie ekwiwalentne dla uszkodzenia (rys.5). 


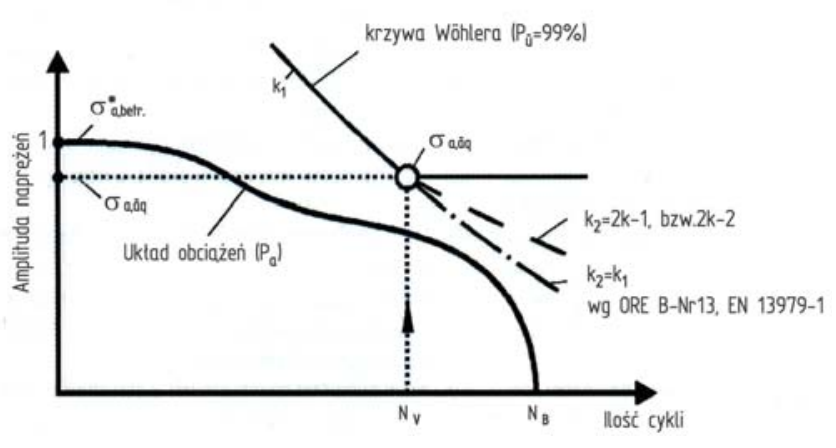

Rys.5. Określenie naprężenia „ekwiwalentnego”, odpowiadającemu uszkodzeniu

Naprężenie ekwiwalentne $\sigma_{a, a ̈ q}$, odpowiadające uszkodzeniu jest obciążeniem o przebiegu sinusoidalnym przy zdefiniowanej ilości cykli obciążeń $\mathrm{N}_{\mathrm{v}}$, które wywoła analogiczne uszkodzenie jak układ obciążeń $\mathrm{z}$ maksymalną wartością naprężenia $\sigma_{\mathrm{a}, \mathrm{betr}} \mathrm{i}$ ilości cykli obciążeń $\mathrm{N}_{\mathrm{B}}$. Naprężenie ekwiwalentne $\sigma_{\mathrm{a} \text {,äq }}$ wyznacza się za pomocą hipotezy Palmgrena-Minera, przy czym wykorzystuje się pochylenie krzywej Wöhlera $\mathrm{k}_{2}=2 \mathrm{k}_{1}$ 1 lub $\mathrm{k}_{2}=2 \mathrm{k}_{1}-2$, powyżej ilości cykli $\mathrm{N}_{\mathrm{v}}$ na podstawie przedłożonych danych, zebranych doświadczeń i zależnie od mechanizmów uszkodzeń. Niniejszy sposób postępowania określa się jako projektowanie dopasowane do warunków eksploatacyjnych, przy czym jest zagwarantowane, że wykazana jest wymagana żywotność, przy której unika się przedwczesnego pęknięcia części decydujących o bezpieczeństwie, do jakich należą osie lub koła zestawów kołowych. Jako podstawę do uszkodzenia bierze się za podstawę „pęknięcie techniczne", przy którym jest zachowana pełna funkcjonalność części (rys.6.)

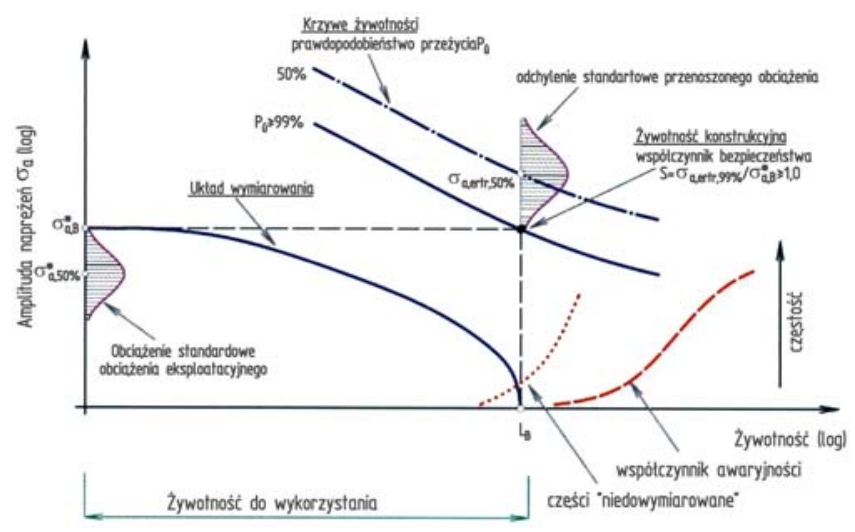

Rys.6. Schematyczna ilustracja projektowania dostosowanego do warunków eksploatacji z odpowiednimi, miarodajnymi parametrami

Jako miarodajną dla żywotności osi przyjęto więc ilość cykli obciążeń $\mathrm{N}_{\mathrm{B}} \approx 10^{9}$, odpowiadającą rzeczywistym warunkom eksploatacyjnym. Przyjęto założenie, że przy odpowiednim zaprojektowaniu osi (zwymiarowaniu osi) prędkość propagacji pęknięcia jest relatywnie mała i można przewidzieć normalne okresy: międzynaprawcze. W przeciwieństwie do tego przy częściach, wykazujących mniejsze wymiary (,konstrukcja niedowymiarowana”) zwiększa się prawdopodobieństwo wystappienia pęknięcia, przy określonych warunkach wytężenia materiału i prowadzi to do istotnie zmniejszonych okresów międzynaprawczych. Tak więc projektowanie osi zgodnie $\mathrm{z}$ obciążeniami eksploatacyjnymi nabiera również znaczenia ekonomicznego.

Dotychczasowe wyniki uzyskane z badań oraz zdobytych doświadczeń z przemysłu pokazały, że występuje logarytmiczny związek pomiędzy żywotnością L i naprężeniem $\sigma$ oraz pomiędzy średnicą przekroju osi $\mathrm{d}$ i żywotnością.

Żywotność osi określa się z zależności:

$$
\mathrm{L}_{\mathrm{X}}=\mathrm{L}_{\mathrm{B}}\left(\frac{\sigma_{a, B}^{*}}{\sigma_{a, b e t r}^{*}}\right)^{k^{*}}
$$

Zależność wymiarową wyznacza się z zależności:

$$
\mathrm{d}_{\mathrm{B}}=\mathrm{d}_{\mathrm{X}}\left(\frac{\mathrm{L}_{\mathrm{B}}}{\mathrm{L}_{\mathrm{X}}}\right)^{1 / n \cdot k^{*}}
$$

gdzie:

$\mathrm{L}_{\mathrm{x}}$ - oczekiwana żywotność przy występowaniu naprężenia eksploatacyjnego $\sigma_{a, b e t r}^{*}$

$\mathrm{L}_{\mathrm{B}}$ - żywotność odpowiadająca projektowaniu

$\sigma_{a, B}^{*}$ - naprężenie, które jest w stanie przenieść

konstrukcja osi, aby osiagnąć żywotność $\mathrm{L}_{\mathrm{B}}$ osi zestawu kołowego;

$\mathrm{d}_{\mathrm{x}}$ - średnica rozpatrywanego przekroju osi

$\mathrm{n}$ - wykładnik naprężenia $(\mathrm{n}=1 \div 2$ dla wieńca $\mathrm{i}$ tarczy koła, $\mathrm{n}=3$ dla osi zestawu kołowego)

$\mathrm{k}^{*}$ - wykładnik żywotności $\left(\mathrm{k}^{*}=5 \div 8\right.$, zależny od gradientu naprężenia, stanu powierzchni i stanu obciążenia w rozpatrywanej strefie elementu konstrukcyjnego).

Z oczekiwanej żywotności $\mathrm{L}_{\mathrm{x}}$ i wymaganej żywotności projektowej $\mathrm{L}_{\mathrm{B}}$ można ustalić wymagane zmniejszenie naprężeń $\sigma_{a, b e t r}^{*}$ względnie zwiększenie średnicy $d_{x}$. $\mathrm{Z}$ drugiej strony z naprężenia $\sigma_{a \text {,betrt }}^{*}$, które jest $\mathrm{w}$ stanie przenieść konstrukcja i ekwiwalentnego naprę-

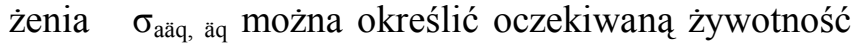
$\mathrm{L}_{\mathrm{x}} \mathrm{W}$ porównaniu do wymaganej żywotności projektowej $\mathrm{L}_{\mathrm{B}}$ :

$$
\mathrm{L}_{\mathrm{X}}=\mathrm{L}_{\mathrm{B}}\left(\frac{\sigma_{\mathrm{a}, \mathrm{betr}}}{\sigma_{\mathrm{a}, \mathrm{aq}}}\right)^{\mathrm{k}^{*}}
$$

Wg tego wzoru, wyrażającego zależność pomiędzy żywotnością i naprężeniami, naprężenie większe o 10 $\% \mathrm{w}$ stosunku do wartości naprężenia, które jest $\mathrm{w}$ stanie przenieść konstrukcja zmniejsza żywotność o 
współczynnik wynoszący 2 przy współczynniku pochylenia krzywej $\mathrm{k}^{*}=6$. Zwiększenie naprężenia o $10 \%$ może być spowodowane zmniejszeniem średnicy przekroju osi o około 3\%. Obliczenia osi tocznych oraz trakcyjnych zespołu trakcyjnego dalekobieżnego ICE TD zostały wykonane $\mathrm{w}$ oparciu odpowiednio o PN-EN 13103:2009 [17] oraz PN-EN 13104:2009 [18].Osie toczne były wykonane $\mathrm{z}$ materiału normalizowanego cieplnie EA1N (24CrMo4), natomiast osie trakcyjne $\mathrm{z}$ materiału ulepszanego cieplnie EA4T (34CrNiMo6). Naprężenia dopuszczalne przyjęto na podstawie ww. norm europejskich. Obydwa typy spełniały więc wymagania wytrzymałości zmęczeniowej we wszystkich strefach ze współczynnikami bezpieczeństwa $S=\sigma_{a, z u l} / \sigma_{a, b e t r} \geq 1$ wg ww. norm. Oszacowanie żywotności wg metodyki projektowania wg widma $\mathrm{z}$ eksploatacji, przy założeniu przebiegu wynoszącego 15 milionów kilometrów prowadzi jednak do zupełnie innych rezultatów. Ponadto z pomiarów eksploatacyjnych ustalono, że uwzględnia się około $20 \%$ większe naprężenie w stosunku do obliczeń wg normy. Jeśli przyjąć, że dotychczasowy przebieg kilometrowy $\mathrm{L}_{\mathrm{X}}$ wynosił 3 miliony kilometrów (aż do ujawnionego pęknięcia w najbardziej wytężonym miejscu w łuku przejściowym), a wymagany wynosi $\mathrm{L}_{\mathrm{B}}=15$ milionów kilometrów to wówczas stosunek obydwu przebiegów wynosi $\mathrm{L}_{\mathrm{B}} / \mathrm{L}_{\mathrm{X}}=5$. Jeśli przyjąć, że $\mathrm{n}=3$ (dla osi) oraz $\mathrm{k}^{*}=6$ to wówczas zgodnie z zależnością (2):

$$
\mathrm{d}_{\mathrm{x}}=\mathrm{d}_{0} \cdot 5^{(1 / 3 \times 6)}=1.09 \cdot \mathrm{d}_{0}
$$

Oznacza to, że w krytycznych miejscach osi średnica powinna wzrosnąc o $9 \%$, aby spełnić wymaganie żywotności $L_{B}=15$ milionów kilometrów. Niniejszy wniosek dotyczył osi napędnej, co przełożyło się na zmianę średnicy osadzenia ze $179 \mathrm{~mm}$ z łukiem przejściowym $160 \mathrm{~mm}$, na średnicę osadzenia $195 \mathrm{~mm} \mathrm{z}$ łukiem przejściowym $174 \mathrm{~mm}$. Z obliczeń wytrzymałościowych za pomocą metody elementów skończonych wynika, że największa koncentracja naprężeń występuje w strefie oznaczonej kolorem czerwonym, która jest przedstawiona na rys.7 (lewa strona). Na rys. 8 jest przedstawiony przełom zmęczeniowy osi zespołu trakcyjnego ICE 3, który wystapił po przebiegu 3 milionów kilometrów i po 7,7 latach eksploatacji (średni przebieg roczny ok. $390000 \mathrm{~km}$ ).

W wyniku analizy pęknięcia osi, które wystapiło w 2008 roku uznano, że jego przyczyną były zanieczyszczenia materiałowe, wynikające $\mathrm{z}$ procesu wytwarzania o długości ok. 0,9 mm, które przekroczyły dopuszczalną wartość.

Pękniecie osi trakcyjnej innego zespołu trakcyjnego dalekobieżnego typu ICE 3 wystapiło na trasie Nürnberg-Chemnitz w dniu 2.12.2002 po rocznej eksploatacji i przebiegu wynoszącym około $350000 \mathrm{~km}$, który doprowadził do wykolejenia, nie powodując

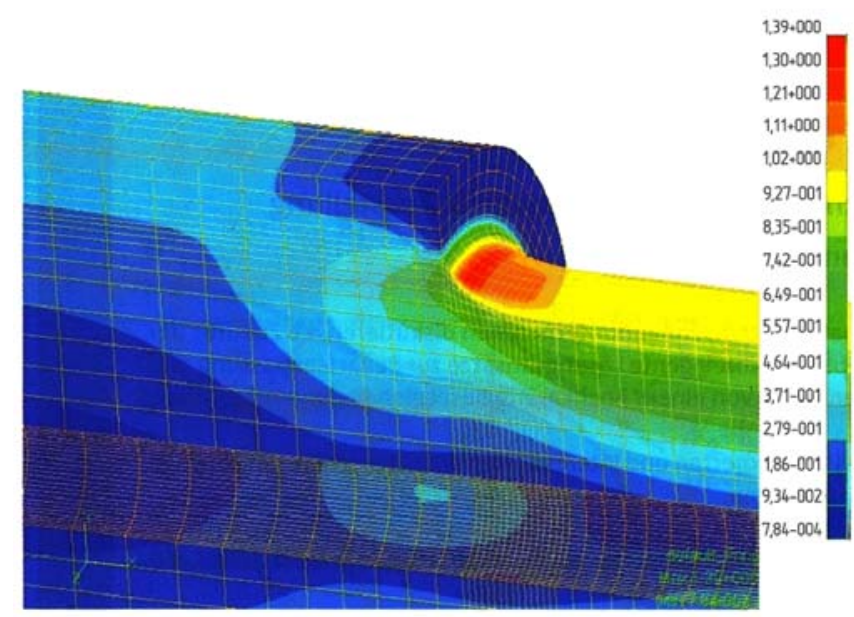

Rys.7. Usytuowanie pęknięcia zmęczeniowego w łuku osi napędnej zespołu trakcyjnego ICE 3, które wystapiło po 7,7 latach eksploatacji i przebiegu 3 milionów kilometrów (analiza wytrzymałościowa metodą elementów skończonych)

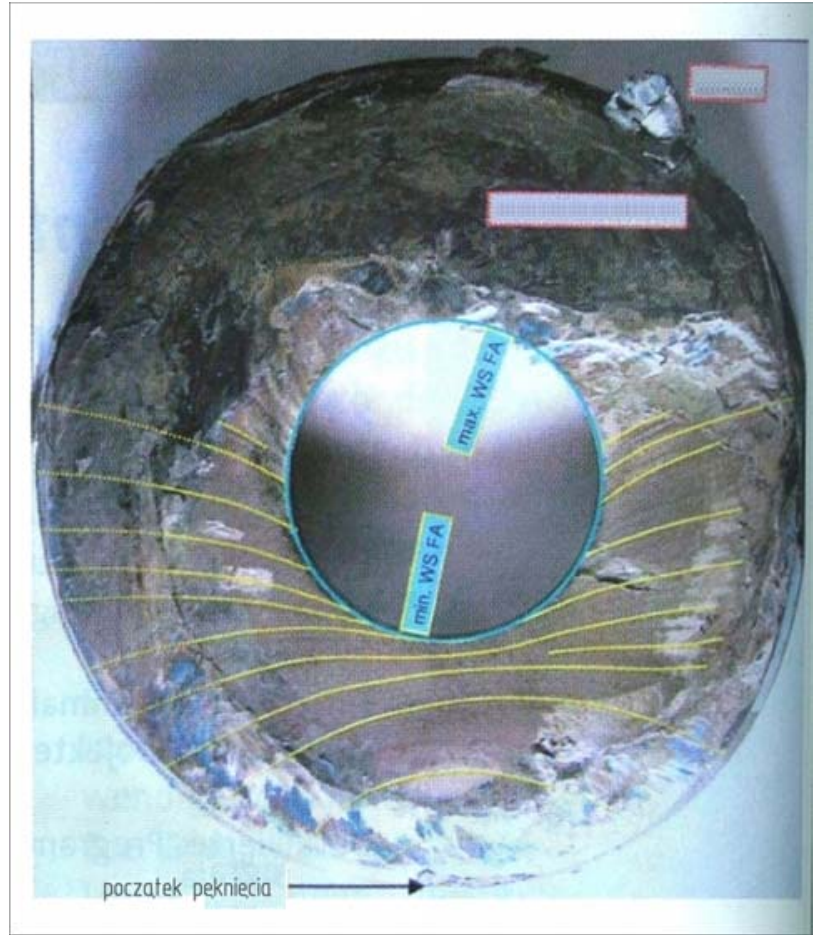

Rys.8. Przełom zmęczeniowy osi napędnej zespołu trakcyjnego dalekobieżnego ICE 3, który wystąpił po 7,7 latach eksploatacji i przebiegu 3 milionów kilometrów

ofiar wśród pasażerów. Przełom zmęczeniowy osi w strefie osadzenia koła został spowodowany korozją cierną $\mathrm{w}$ tym rejonie $\mathrm{i}$ jest przedstawiony na rys.9 $\mathrm{i}$ powstało w tym samym miejscu jak na rys.7.

Graficzne przedstawienie wytrzymałości zmęczeniowej osi zestawów kołowych wg obliczeń zgodnie z normą PN-EN 13103 (osie toczne) [17] oraz PN-EN 13104 (osie trakcyjne) [18] w zależności od ilości cykli obciążeń znajduje się na rys.10. 


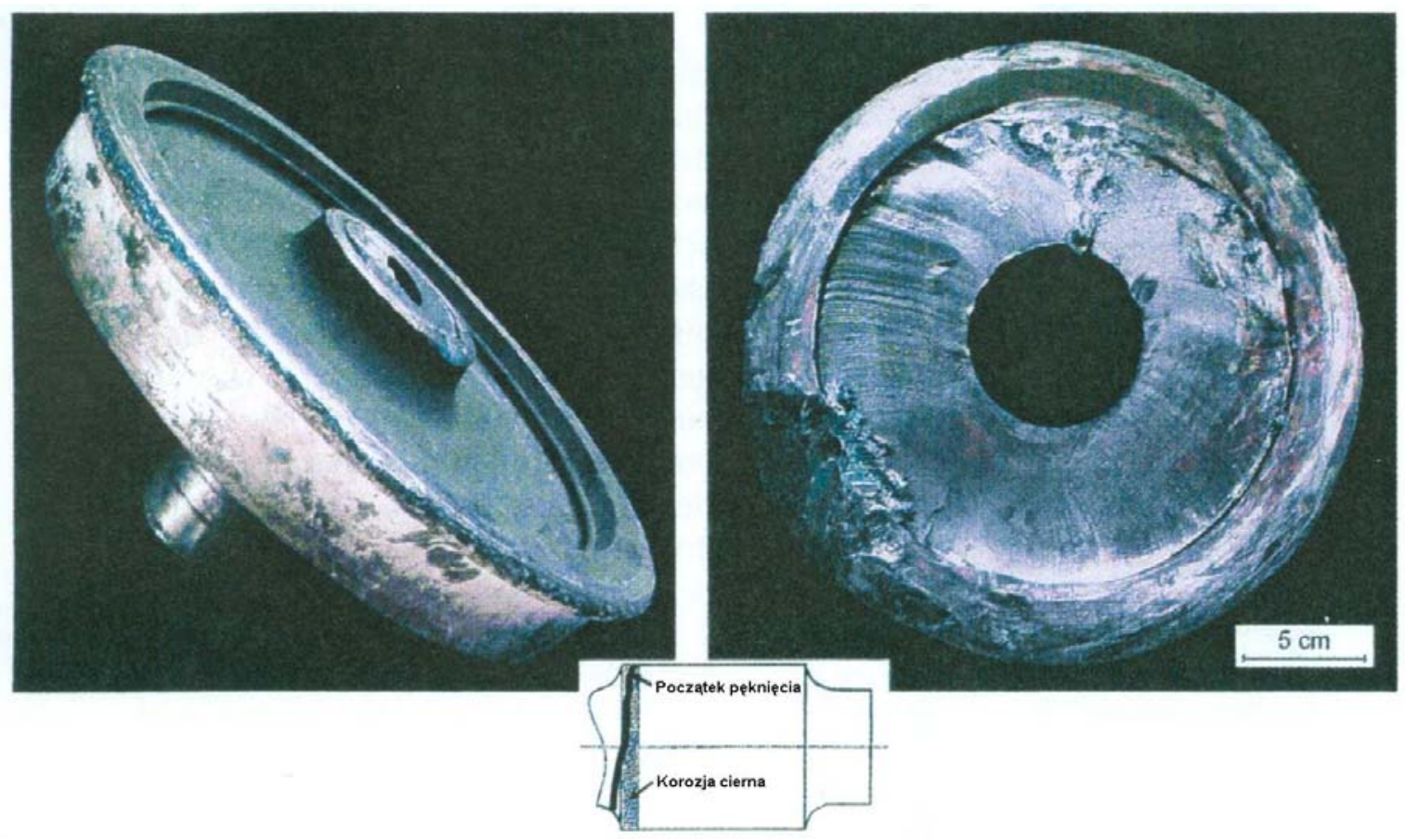

Rys.9. Przełom zmęczeniowy osi napędnej zestawu kołowego zespołu trakcyjnego dalekobieżnego ICE po rocznym przebiegu $350000 \mathrm{~km}$

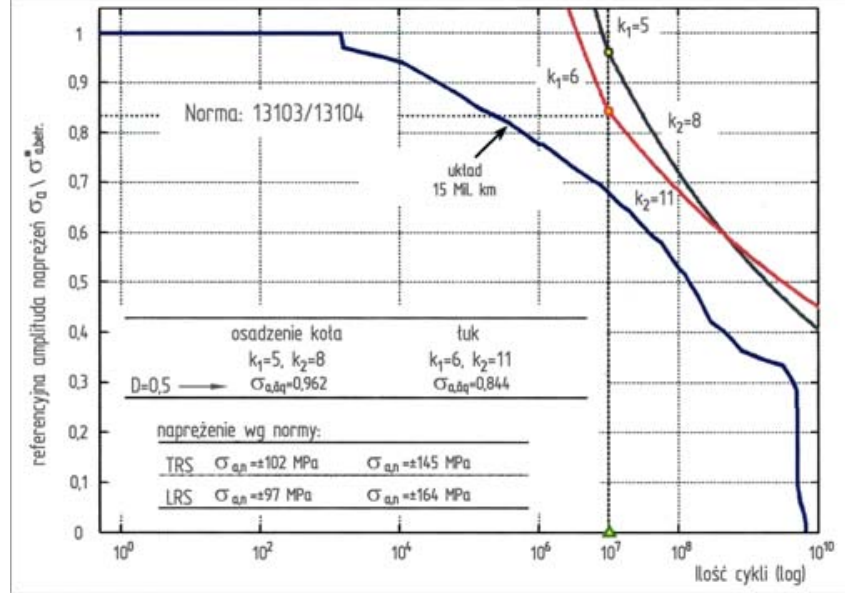

Legenda:

TRS - zestaw kołowy napędny (niem. Treibradsatzwelle)

LRS - zestaw kolowy toczny (niem. Laufradsatazwelle)

Rys.10. Oszacowanie wytrzymałości zmęczeniowej osi zespołu trakcyjnego ICE (osadzenie koła na osi) w zależności od ilości cykli obciążeń

Jak wynika z przebiegu krzywej zmęczenia, naprężenia pomierzone są o ok. $30 \%$ wyższe aniżeli przedstawione w normie PN-EN13104:2009 [18]. Okazuje się, że $\mathrm{w}$ takim przypadku projektowanie zestawów kołowych wg normy musi prowadzić bezwzględnie do uszkodzeń, ponieważ wychodzi się z fałszywych założeń. Po przejściowym zatrzymaniu 19-tu zespołów trakcyjnych typu ICE-3 dokonano wymiany wszystkich osi. Nowe osie posiadały nieznaczną modyfikację geometryczną i były pokryte molibdenem. W wyniku dokonanych zabiegów konstrukcyjnych można było osiagnąć tylko 10 letnią żywotność. W związku z powyższym proponuje się:
$\Rightarrow$ projektowanie obliczeniowe (konstrukcja) na podstawie obciążeń i danych obliczeniowych

$\Rightarrow$ sprawdzenie wytrzymałości za pomocą prób

$\Rightarrow$ sprawdzenie obciążeń na podstawie pomiarów na trasie

$\Rightarrow$ ostateczne ustalenie projektowanej konstrukcji, włączenie $\mathrm{z}$ planem przeglądów oraz kontroli międzynaprawczych.

Jako dodatkowy środek zaradczy, zwiększający niezawodność kursujących dalekobieżnych pojazdów trakcyjnych, przystosowanych do wysokich prędkości należy uznać kontrolę za pomocą sensorów właściwości eksploatacyjnych, między innymi kół i osi. Ten nowoczesny i kontrowersyjny pogląd na odmienne podejście do projektowania osi jest oparty na przekonaniu, że każdy doświadczony inżynier powinien mieć świadomość, że normy obowiązujące w kolejnictwie odpowiadają najniższemu poziomowi technicznemu, który jest uzgodniony przez fachowców i odbiegaja mocno aktualnego stanu technicznego. Metodyka obliczeń osi dla takich przypadków powinna być porównana $\mathrm{z}$ innymi metodykami, które choćby są stosowane w innych działach techniki, do których zalicza się budowę samolotów lub samochodów. W wyniku przedstawionego rozumowania zaleca się, aby na instalować odpowiednie sensory $\mathrm{w}$ nowoczesnych pojazdach szynowych, aby dokonywać kontroli własności dynamicznych układów biegowych, a w szczególności osi i kół zestawów kołowych. Dodatkowym wsparciem dla nowego podejścia do projektowania zestawów kołowych jest wielkość niezrównoważonego przyspieszenia $\mathrm{w}$ zależności od zastosowanej przechyłki na łukach toru. Wyniki te są zebrane w tabeli 3. 
Wielkości niezrównoważonego przyspieszenia w kierunku poprzecznym w zależności od przechyłki toru dla osi napędnych i tocznych wg [5]

Tabela 3

\begin{tabular}{|c|c|c|c|c|}
\hline $\begin{array}{c}\text { Niedostateczność } \\
\text { przechylki }\end{array}$ & Kąt Frouda & $\begin{array}{c}\text { Niezrównoważone } \\
\text { przyspieszenie od- } \\
\text { środkowe }\end{array}$ & $\begin{array}{c}\text { Wspólczynnik dy- } \\
\text { namiczny dla ze- } \\
\text { stawu kolowego } \\
\text { napędnego oraz } \\
\text { prowadzącego ze- } \\
\text { stawu kołowego } \\
\text { tocznego }\end{array}$ & $\begin{array}{c}\text { Wspólczynnik } \\
\text { dynamiczny dla } \\
\text { nieprowadzące- } \\
\text { go } \\
\text { kołstawu } \\
\text { tocznego }\end{array}$ \\
\hline $\mathbf{I}$ & $\boldsymbol{\beta}_{\mathbf{q c}}$ & $\mathbf{a}_{\mathbf{q c}}$ & $\mathbf{f}_{\mathbf{y}}$ & $\mathbf{f}_{\mathbf{y}}$ \\
\hline$[\mathrm{mm}]$ & {$[\mathrm{rad}]$} & {$\left[\mathrm{m} / \mathrm{s}^{2}\right]$} & {$[-]$} & {$[-]$} \\
\hline 100 & 0,0667 & 0,65378 & 2,625 & 2,250 \\
\hline 130 & 0,0867 & 0,84991 & 2,019 & 1,731 \\
\hline 150 & 0,1000 & 0,98067 & 1,750 & 1,500 \\
\hline 153 & 0,1020 & 1,00028 & 1,716 & 1,471 \\
\hline 160 & 0,1067 & 1,04604 & 1,641 & 1,406 \\
\hline 168 & 0,1120 & 1,09834 & 1,563 & 1,339 \\
\hline 180 & 0,1200 & 1,17680 & 1,458 & 1,250 \\
\hline 183 & 0,1220 & 1,19641 & 1,434 & 1,230 \\
\hline 240 & 0,1600 & 1,56906 & 1,094 & 0,938 \\
\hline 275 & 0,1833 & 1,79789 & 0,955 & 0,818 \\
\hline 300 & 0,2000 & 1,96133 & 0,875 & 0,750 \\
\hline 306 & 0,2040 & 2,00056 & 0,858 & 0,735 \\
\hline
\end{tabular}

Pojazd na przechyłce łuku toru jest przedstawiony na rys. 11

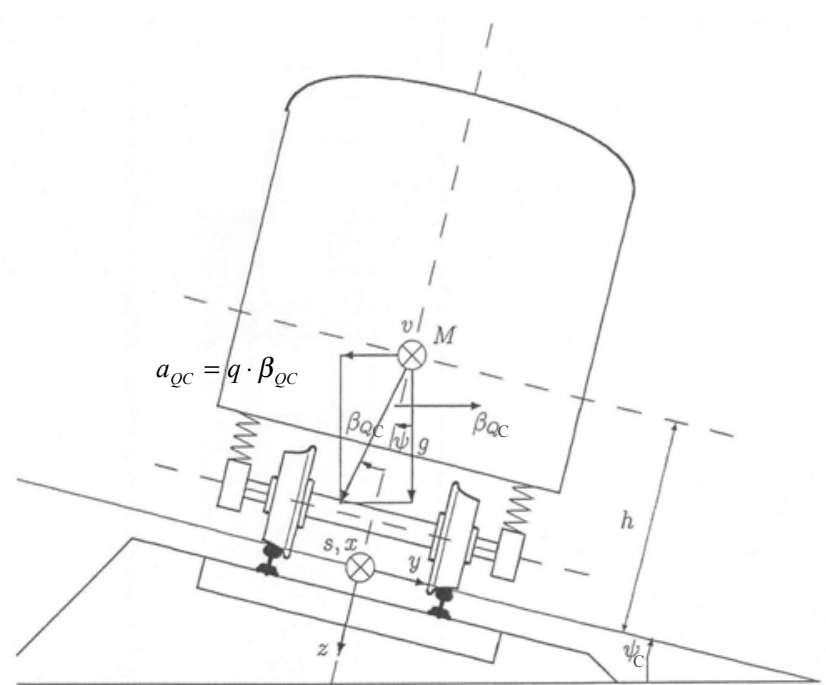

Rys.11. Pojazd na przechyłce toru

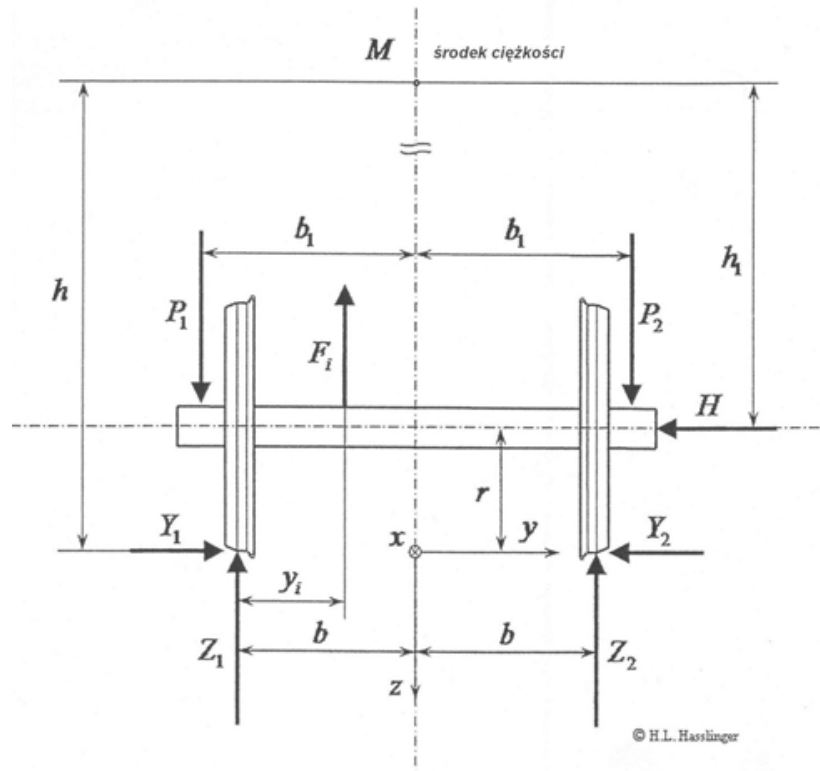

Rys.12. Schemat obciążenia zestawu kołowego siłami pionowymi oraz poprzecznymi 
Pudło pojazdu wraz z ładunkiem, znajdujące się na przechyłce łuku toru jest poddane obciążeniu odśrodkowemu $\mathrm{a}_{\mathrm{QC}}=\mathrm{g} \beta_{\mathrm{QC}}$. Poprzeczną siłę łożyskową można wyznaczyć ze wzoru:

$$
\mathrm{H}=\mathrm{f}_{\mathrm{y}} \cdot \mathrm{a}_{\mathrm{QC}} \cdot \mathrm{m}_{1}
$$

gdzie:

$\mathrm{f}_{\mathrm{y}}-\quad$ współczynnik Frouda

$\mathrm{a}_{\mathrm{qc}}$ - niezrównoważone przyspieszenie w kierunku poprzecznym

$\mathrm{m}_{1}$ - masa przypadająca na czopy zestawu kołowego

(włącznie z masą łożysk i korpusem maźnicy).

Po wstawieniu $\mathrm{a}_{\mathrm{QC}}=\mathrm{g} \beta_{\mathrm{QC}}$ do wzoru (5) otrzymuje się:

$$
\mathrm{H}=\mathrm{f}_{\mathrm{y}} \cdot \mathrm{g} \cdot \beta_{\mathrm{QC}} \cdot \mathrm{m}_{1}
$$

Siłę pionową $\mathrm{P}_{1}$ działającą na lewy czop osi zestawu kołowego wyznacza się z zależności:

$$
\mathrm{P}_{1}=\frac{1}{2} \cdot\left(\mathrm{f}_{\mathrm{Z}}+\frac{\mathrm{h}_{1}}{\mathrm{~b}_{1}} \cdot \mathrm{f}_{\mathrm{y}} \cdot \beta_{\mathrm{QC}}\right) \cdot \mathrm{g} \cdot \mathrm{m}_{1}
$$

Siłę pionową $\mathrm{P}_{2}$ działającą na prawy czop osi zestawu kołowego wyznacza się z zależności:

$$
\mathrm{P}_{2}=\frac{1}{2} \cdot\left(\mathrm{f}_{\mathrm{Z}}-\frac{\mathrm{h}_{1}}{\mathrm{~b}_{1}} \cdot \mathrm{f}_{\mathrm{y}} \cdot \beta_{\mathrm{QC}}\right) \cdot \mathrm{g} \cdot \mathrm{m}_{1}
$$

Analizując niezrównoważone przyspieszenia $\mathrm{a}_{\mathrm{qc}} \mathrm{w}$ zależności od przechyłki toru, w raporcie ORE/ERRI B136/Rp.11/D [21] oraz PN-EN 13103:2009 [17] przyjęto wartość przyspieszenia poprzecznego dla osi tocznych $\beta=0,15 \mathrm{~g}=1,47 \mathrm{~m} / \mathrm{s}^{2}$ natomiast $\mathrm{w}$ przypadku osi napędnych PN-EN 13104:2009 [18] wartość $\beta=0,175 \mathrm{~g}=1,71 \mathrm{~m} / \mathrm{s}^{2}$.W przypadku bardzo dużych przechyłek toru, przeznaczonych dla pojazdów trakcyjnych z przechylnym pudłem niezrównoważone przyspieszenie jest znacznie większe aniżeli przyjęte w PN-EN 13103:2009 [17] oraz PN-EN 13104:2009 [18]. Widoczne to jest dla przechyłek toru o wartości większej niż $240 \mathrm{~mm}$. W związku z powyższymożna wnioskować o trzech istotnych punktach, w których normy PN-EN 13103:2009 [17] oraz PN-EN 13104:2009 [18] posiadają istotne mankamenty, a mianowicie pominięcie:

$\Rightarrow$ masy zestawu kołowego

$\Rightarrow$ kołysania i ewentualnego przechyłu pudła

$\Rightarrow$ zbyt małe współczynniki bezpieczeństwa dla dopuszczalnych naprężeń przy bardzo dużych niedostatecznościach przechyłki.

\section{AUTOMATYCZNY MONITORING ZESTA- WÓW KOLOWYCH WAGONÓW TOWA- ROWYCH}

Jednym $\mathrm{z}$ istotnych elementów zwiększenia niezawodności zestawów kołowych jest ich monitoring. Jak wynika niemieckich doświadczeń eksploatacyj- nych kolei niemieckich około 100000 wagonów towarowych jest w codziennej eksploatacji. Okres międzynaprawczy wynosi 6 lat i ma być wydłużony nawet do 8 lat. W przeciwieństwie do pojazdów trakcyjnych, których przeglądy są zależne od przebiegu kilometrowego, wagony towarowe podlegają naprawom okresowym, które są związane z określonymi czasookresami. $Z$ tego też względu jest trudne do ustalenia jaki przebieg kilometrowy posiadaja zestawy kołowe wagonów towarowych. W tej sytuacji Federalny Urząd Kolejnictwa (EBA) w Bonn wydał rozporządzenie jesienią 2009 roku, aby dokonać kontroli zestawów kołowych 4450 wagonów towarowych. Przeprowadzona kontrola wykazała wady, wpływające na bezpieczeństwo eksploatacyjne. W związku z powyższym powstał plan wdrożenia monitoringu zestawów kołowych, na podstawie którego można by zarejestrować przebieg kilometrowy. Przedsiębiorstwo Eureka Navigation Solutions AG w Monachium wraz z niemieckim koncernem Deutsche Telekom rozwinęło nowoczesny rozwiązanie RodoTAG. Rejestrator, miniaturowej wielkości można zainstalować w ciagu kliku minut za pomocą pasków taśm szybkomocujących (rys.13).

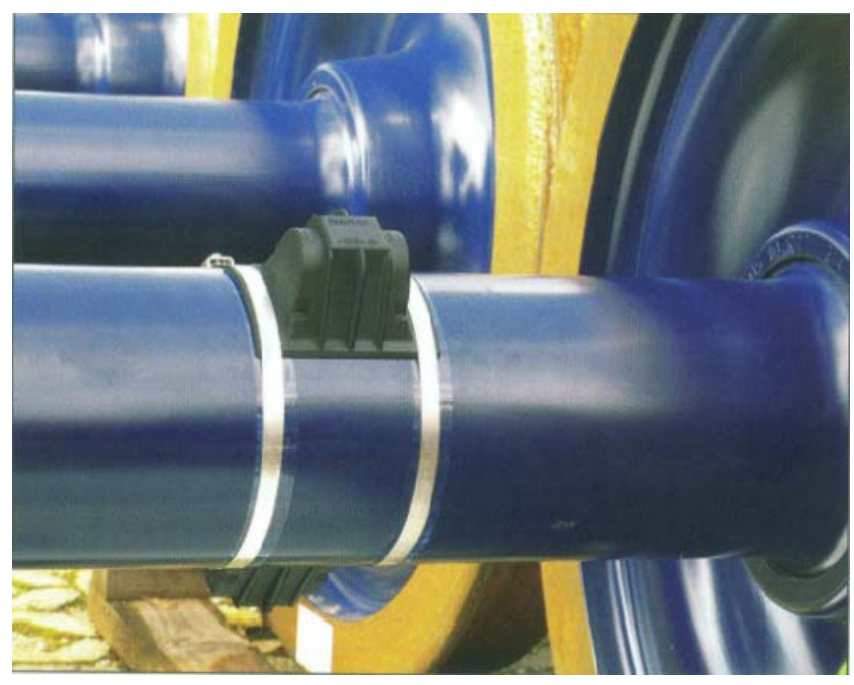

Rys.13. Urządzenie RodoTAG, zamocowane na osi zestawu kołowego wagonu towarowego wg [2]

Sensory zainstalowane są wewnątrz urządzenia i mierzą prędkość obrotową zestawu kołowego. Na podstawie takiego parametru można ustalić prędkość i przebieg wagonu. Urządzenie to jest przystosowane do następujących warunków eksploatacyjnych:

$\Rightarrow$ najniższa temperatura otoczenia: $-40^{\circ} \mathrm{C}$

$\Rightarrow$ siły bezwładności wynoszące do $80 \mathrm{~g}=785$ $\mathrm{m} / \mathrm{s}^{2}$

$\Rightarrow$ orientacyjny czasookres eksploatacji: siedem lat.

Jedną z zalet nowego urządzenia typu RodoTAG są jego zdolności komunikacyjne. Przekazywanie danych odbywa się za pomocą modułu GSM przez sieć radiową do centrali Deutsche Telekom gdzie podlegają 
obróbce, a następnie są przekazywane do użytkownika wagonu lub do systemu komunikacyjnego $\mathrm{T}$, zbudowanego przez filię firmy Deutsche Telekom. Istotną korzyścią wprowadzenia nowego systemu jest możliwość wdrożenia nowoczesnego sytemu konserwacyjno-naprawczego, który może się odbywać w zależności od rzeczywistych przebiegów kilometrowych wagonów towarowych. Jest to tym bardziej uzasadnione, że niektóre wagony towarowe mają bardzo małe przebiegi kilometrowe $\mathrm{w}$ skali rocznej, a inne z kolei posiadają znaczące przebiegi, wynoszące $150000 \mathrm{~km}$ na rok. $Z$ tego można wnioskować, że wagony towarowe o małym przebiegu nie będą podlegały wcześniejszemu, natomiast $\mathrm{z}$ większym przebiegiem zbyt późnemu przeglądowi. Wymiana zużytych części we właściwym czasie przyczynia się do zmniejszenia kosztów przeprowadzenia napraw i konserwacji. Wielu przewoźników kolejowych przetestowało nowy system w praktyce i wyposażyło swój tabor wagonowy w urządzenie RodoTAG już od września 2010 roku. Istotną zaletą nowego systemu jest nie tylko możliwość dokładnej rejestracji przebiegów kilometrowych, ale również możliwość automatycznej identyfikacji zestawów kołowych w miejscach naprawczych lub serwisowych. Wdrożenie nowego systemu wspomagają firmy telekomunikacyjne Eureka i Deutsche Telekom.

\section{WNIOSKI}

Jak widać $\mathrm{z}$ przeprowadzonej analizy tendencji rozwojowych problem, związany z zasadami konstrukcji osi zestawów kołowych pojazdów szynowych jest wciąż problemem otwartym. Wynika to z trendów rozwojowych kolejnictwa europejskiego oraz światowego, polegającym na zwiększeniu efektywności przewozowej przez zwiększenie nacisków zestawów kołowych na tor oraz prędkości pojazdu. Jednoczesne zwiększenie prędkości pojazdów i ich przebiegów, niewątpliwie przyczyniło się do znaczącego przyrostu cykli obciążeń (tzw. „zakres gigacyklowy”). Zakres ten nie był wcześniej badany na stanowiskach stacjonarnych. Pęknięcia osi zestawów kołowych dalekobieżnych zespołów trakcyjnych wysokich prędkości są nowym doświadczeniem, które powinno być gruntownie przeanalizowane i uwzględnione w PN-EN 13103 [17] oraz PN-EN13104 [18]. Problem diagnostyki, przeglądów uzależnionych od faktycznego przebiegu kilometrowego jest też bardzo istotny, zwłaszcza dla takich pojazdów jak wagony towarowe. Próba skodyfikowania wad zestawów kołowych $\mathrm{w}$ formie katalogu uszkodzeń jest istotnym kierunkiem, zwiększającym bezpieczeństwo zestawów kołowych w eksploatacji. Jest to jeszcze jedne dowód na to, że o bezpieczeństwie i niezawodności osi zestawów kołowych decyduje aktualny stan techniczny, a nie wiek zestawów kołowych, jeśli nie jest on powiązany z przebie- giem kilometrowym. Jeśli przyjąć, że roczny przebieg kilometrowy wagonu towarowego wynosi 50000 $\div 100000 \mathrm{~km}$, to wówczas podczas 30 letniej eksploatacji można się spodziewać łącznego przebiegu 1,5 $\div 3$ milionów kilometrów. Przebieg ten jest $5 \div 10$ razy mniejszy od zakładanego dla dalekobieżnych zespołów trakcyjnych wysokich prędkości. Należy wziąć również pod uwagę specyfikę transportu kolejowego ładunków, polegającego na tym że część przejazdów odbywa się w stanie próżnym lub częściowo załadowanym, co powoduje że nie można w takim przypadku mówić o pełnym cyklu obciążenia. Ww. metody, zmierzają jednak do ustalenia metodyki obliczeniowej oraz okresu pomiędzy kontrolami i naprawami w zależności od przebiegu kilometrowego, a nie „sztywno" określonych okresów międzynaprawczych. Jest to kolejna próba dopasowania konstrukcji do rzeczywistych warunków eksploatacyjnych. Z przedstawionej analizy różnych metod, służących do zwiększenia niezawodności zestawów kołowych i znajdujących się w eksploatacji wynika również ich dostosowanie do specyfiki pojazdu. Wagony towarowe posiadaja znacznie mniejsze przebiegi kilometrowe aniżeli zespoły trakcyjne wysokich prędkości. Gruntowne rozpoznanie rzeczywistych przebiegów eksploatacyjnych oraz działających obciążeń pozwala na rzeczywiste prognozowanie faktycznej żywotności osi zestawów kołowych. Przedstawione podejście kładzie nacisk na doświadczalne zbieranie danych $\mathrm{z}$ eksploatacji, a nie bezkrytyczne przyjmowanie metodyki projektowania przedstawionej w normach europejskich, które podlegaja zmianom $\mathrm{w}$ zależności od aktualnego poziomu technicznego, akceptowalnego $\mathrm{z}$ punktu widzenia państw członkowskich Unii Europejskiej. Z przedstawionych analiz wytrzymałości zmęczeniowej osi zestawów kołowych, wynika konieczność utrzymywania jej na jak najwyższym poziomie, którą można zapewnić stosując zabiegi technologiczne.

\section{Literatura}

[1] Engelmann J., Wirtgen J., Nicolin J.: Europäisches Aktionsprogramm für die Güterwagensicherheit. Eisenbahntechnische Rundschau Nr. 11/2010.

[2] Gökcek E., Behrends V.: Automatisches Radsatzmonitoring für Güterwagen. ETR-Eisenbahntechnische Rundschau Nr.11/2010

[3] Grubisic V., Fischer V.: Sichere Bemessung von ICE-Radsatzwellen. Eisenbahntechnische Rundschau, Nr.1-2, 2011

[4] Gumbiowski M., Poschmann I., Bowi M., Bardehle T.: Oberfläschenschutz von Radsätzen. Eisenbahningenieur Nr.9/2002.

[5] Hasslinger H.: Lastannahmen für RadsatzwellenBestandsanalyse. Eisenbahntechnische Rundschau. Nr. 12, 12.2009.

[6] Liedgens K.: Inspektionskonzept für Radsatzwellen bei der Hamburger Hochbahn. Eisenbahningenieur. Nr. 3/2010. 
[7] Malkiewicz T.: Metaloznawstwo stopów żelaza. PWN Warszawa-Kraków. Wydanie III.1976.

[8] Murawa F., Winkler M..: Randschichtbehandelte Radsatzwellen. Eisenbahningenieur $\quad$ Nr.7/2007.

[9] Richard A., Sander M., Wirxel M., Lebehahn J.: Ermittlung von Inspektionsinterwallen mittels Risswachstumsuntersuchungen. Eisenbahningenieur. Luty 2010.

[10] Sobaś M.: Diagnostyka osi zestawów kołowych układów biegowych pojazdów trakcyjnych i tocznych. Pojazdy Szynowe $n r$ 4/2010

[11] Sobaś M: Kryteria obiektywnej oceny prognozowanych stanów osi zestawów osi zesta- wów kołowych pojazdów trakcyjnych. Pojazdy Szynowe $n r$ $1 / 2011$.

[12] Sobaś M: Zabiegi technologiczne zwiększajace żywotność osi zestawów kołowych. Pojazdy Szynowe nr 4/2011

[13] EN 473: Kwalifikacja i certyfikacja personelu do badań nieniszczacych. Ogólne zasady. Marzec 1993.

[14] EN 45013: Ogólne wymagania dotyczqce opinii $i$ akredytacji placówek certyfikujacych (ISO/IEC Tom 61:1996).1998.
[15] Karta UIC 811-1: Warunki techniczne na dostawe osi zestawów kołowych dla pojazdów trakcyjnych $i$ wagonów.

[16] Karta UIC 960: Kwalifikacja i certyfikacja personelu odpowiedzialnego za prowadzenie badań nieniszczacych elementów zespołów pojazdów szynowych $w$ procesie ich utrzymania.2-gie wydanie z grudnia 2001.

[17] PN-EN 13103:2009: Kolejnictwo. Zestawy kołowe $i$ wózki. Osie zestawów kołowych tocznych. Zasady konstrukcji.

[18] PN-EN 13104:2009: Kolejnictwo. Zestawy kołowe $i$ wózki. Osie zestawów kołowych napędnych. Zasady konstrukcji.

[19] PN-EN 13261+A1:2011: Kolejnictwo. Zestawy kołowe $i$ wózki. Osie. Wymagania dotyczqce wyrobu.

[20] PN-93/K-91045: Pojazdy trakcyjne. Osie zestawów kołowych. Wymagania i badania.

[21] Raport ORE/ERRI B136/Rp.11/D: Zestawy kołowe z nasadzanymi tożyskami tocznymi. Konstrukcja, utrzymanie i standaryzacja. Obliczenie osi zestawów kołowych dla wagonów towarowych $i$ osobowych. Utrecht, kwiecień 1979.

[22] OR-9666: „Diagnostyka układów biegowych pojazdów tocznych i trakcyjnych. IPS „Tabor” Wrzesień 2010 . 